\title{
HPV vaccination is fundamental for reducing or erradicate penile cancer | Opinion: NO
}

Paulo Ornellas ${ }^{1}$, Antonio Augusto Ornellas ${ }^{2,3}$

${ }^{1}$ Departamento de Patologia, Universidade do Estado do Rio de Janeiro, Rio de Janeiro, RJ, Brasil; ${ }^{2}$ Departamento de Urologia, Instituto Nacional do Câncer (INCA), Rio de Janeiro, RJ, Brasil; ${ }^{3}$ Instituto de Pós-Graduação Médica Carlos Chagas, Rio de Janeiro, RJ, Brasil

Keywords: Human papillomavirus; Penile Neoplasms; Vaccination, Male

Human papillomavirus (HPV) is a DNA virus that presents tropism for epithelial cells, causing infections of the skin and mucous membranes. It is transmitted by direct contact of a healthy skin or mucosa with an affected skin or mucosa. Until now, more than 200 types of HPVs have been discovered (1). Approximately 30 types infect the anal and genital mucosa. Types that can also be detected in the oral mucosa are classified according to risk of causing lesions or their potential for malignancy. Such as "low risk" are included types 6 and 11 (more incidents) and as "high risk" the types 16, 18, 31, 33, 35, 39, 45, 51, 52, 56, 58, 59 and 66 (2). Human papillomavirus (HPV), a sexually transmitted infection, is responsible for $99.7 \%$ of cases of cervical cancer (3) and 530,000 new cases of cervical cancer globally every year (4). In addition, HPV is also responsible for some head and neck cancers, penile cancers and the majority of anal cancers (5). The incidence of these cancers is on the rise. Globally, HPV types 16 and 18 are responsible for 38,000 (85\%) new cases of head and neck cancers and 35,000 (87\%) cases of anal cancers (4).

The main focus of global vaccine programs has been prevention of cervical cancer, through prevention of oncogenic HPV infection, the necessary cause of squamous and glandular cervical carcinomas $(6,7)$. The most robust available data regarding HPV vaccines regards cervical intraepithelial neoplasia and cervical cancer. A recent 10-year review and meta-analysis of several randomized controlled trials (RCT) cited efficacy from 89.8-100\% in a follow-up of 34.9 months to 9.4 years (8). The most common adverse event was pain at the injection site and any serious adverse events were not determined to be vaccine-related (8). Another 10-year review found similar efficacy, specifically of the bivalent and 9-valent vaccines, again, in CIN2+ lesions (9). However, regarding male HPV cases, a significant concern is the low rate of seroconversion after natural infection (10). In addition, it has been suggested that HPV antibody seropositivity does not provide significant immunity to future infections like it does in women (11). Fortunately, the quadrivalent HPV vaccine has been shown to be highly immunogenic in men age 16 to 26, with seroconversion by month 7, remaining elevated even at 36 months, with titers comparable to those in women (12). In Sweden, the current HPV Immunization Program includes only young females, and coverages above 50\% in such programs are suggested to give herd immunity $(13,14)$. Since the introduction of the HPV vaccine in Sweden, the incidence of anogenital warts has decreased among both the vaccinated female population and the unvaccinated male population, suggesting that herd immunity has been achieved $(15,16)$. However, among males having sex with males, herd immunity has not yet been proven, which is 
why a recent modeling study recommended targeted prevention strategies to reach this population (17).

Penile cancer is a heterogeneous disease with respect to HPV infection, with the association with penile infection dependent on the histology $(18,19)$. It is uncertain whether cancers involving HPV infection have better survival profiles than cancers without HPV infection. In a study with 82 penile cancer patients, 30.5\% of tumors had HPV DNA, with HPV 16 being the most prevalent. This study demonstrated no association between HPV negative and positive patients when considering lymph node metastasis $(\mathrm{P}=0.386)$ and 10 year survival rate $(68.4 \%$ vs. $69.1 \% ; \mathrm{P}=0.83)$ (20). In another study with 29 patients with invasive squamous cell carcinoma of penis (SCCP), 31\% of tumors had either HPV-16 or HPV-18 DNA. This study found no difference between HPV negative and positive patients in terms of nodal metastasis or survival even after adjustment control for tumor stage (21). However, these results differ from another which examined HPV status as a prognostic indicator in 171 penile cancer patients. In this study, high-risk HPV DNA was found in 29\% of tumors, with 76\% containing HPV-16. High-risk HPV was associated with improved 5-year disease-specific survival (78\% vs. 93\%; $\mathrm{P}=0.03)$. Additionally, high-risk HPV was an independent predictor of disease specific mortality in multivariate analysis [hazard ratio (HR), 0.14; 95\% CI, 0.03-0.63; P=0.01] (22). Regarding all these studies, we can notice that the presence HPV DNA in SCCP is not much higher than $30 \%$. It means that approxima-

\section{REFERENCES}

1. Haedicke J, Iftner T. Human papillomaviruses and cancer. Radiother Oncol. 2013;108:397-402.

2. Bocardo, E, Villa, L.L. Vírus e Câncer, capítulo 13; em Oncologia Molecular; Carlos Gil Ferreira e José Cláudio Casali da Rocha (editores), Rio de Janeiro: Atheneu; ed. 2. 2010; p. 183-4.

3. Walboomers JM, Jacobs MV, Manos MM, Bosch FX, Kummer JA, Shah KV, ET AL. Human papillomavirus is a necessary cause of invasive cervical cancer worldwide. J Pathol. 1999;189:12-9. tely $70 \%$ of patients with SCCP will still have the disease even if all males received the vaccine. SCCP have a low association with HPV, whereas warty/basaloid cancers are strongly associated with HPV (23). In addition, preliminary data indicate a prevalence of $54.6 \%$ of HPV cases among the Brazilian population aged 16 to 25 years, 38.4\% of which are of high risk for the development of cancer (24). he infection can manifest itself in two ways: clinical and subclinical and it is estimated that only about 5\% of people infected with HPV will develop some form of manifestation (25). As penile cancer accounts for only $2.7 \%$ of male malignancies in Brazil (26), we can roughly estimate that few patients with HPV will develop penile cancer. Among HPV positive patients, those with high-risk HPV would be more likely to develop penile cancer.

Therefore, the male public HPV vaccination is a good measure to prevent not just cervical cancer but some head and neck cancers, some penile warts and the majority of anal cancers. However, it is not clear if it will be enough to eradicate or reduce the prevalence of penile cancer. Increased patient education along with prevention strategies such us condom use, hygienic measures, smoking cessation, and avoidance of chronic inflammatory states can have considerable impact on pathogenesis of pre-cancerous lesions of the penis. Although, the adoption of HPV vaccination has led to some success in female HPV-related cancers, the results are yet to be elucidated in the male population. It is necessary further long-term studies to declare that HPV vaccination is effective against SCCP.

4. [No authors]. Human papillomavirus vaccines: WHO position paper, May 2017. Wkly Epidemiol Rec. 2017;92:241-68.

5. Parkin DM, Bray F. Chapter 2: The burden of HPVrelated cancers. Vaccine. 2006;24 (Suppl 3):S311-25.

6. Koutsky L. The epidemiology behind the HPV vaccine discovery. Ann Epidemiol. 2009;19:239-44.

7. Bouvard V, Baan R, Straif K, Grosse Y, Secretan B, El Ghissassi F, ET AL. WHO International Agency for Research on Cancer Monograph Working Group. A review of human carcinogens--Part B: biological agents. Lancet Oncol. 2009;10:321-2. 
8. Angioli R, Lopez S, Aloisi A, Terranova C, De Cicco C, Scaletta $G$, $t$ al. Ten years of HPV vaccines: State of art and controversies. Crit Rev Oncol Hematol. 2016;102:65-72.

9. Harper DM, DeMars LR. HPV vaccines - A review of the first decade. Gynecol Oncol. 2017;146:196-204. Erratum in: Gynecol Oncol. 2017;147:489.

10. Giuliano AR, Viscidi R, Torres BN, Ingles DJ, Sudenga $S L$, Villa $L L$, et al. Seroconversion Following Anal and Genital HPV Infection in Men: The HIM Study. Papillomavirus Res. 2015;1:109-115.

11. Lu B, Viscidi RP, Wu Y, Lee JH, Nyitray AG, Villa LL, et al. Prevalent serum antibody is not a marker of immune protection against acquisition of oncogenic HPV16 in men. Cancer Res. 2012;72:676-85.

12. Hillman RJ, Giuliano AR, Palefsky JM, Goldstone S, Moreira ED Jr, Vardas E, et al. Immunogenicity of the quadrivalent human papillomavirus (type 6/11/16/18) vaccine in males 16 to 26 years old. Clin Vaccine Immunol. 2012;19:261-7.

13. Östensson E, Silfverschiöld M, Greiff L, Asciutto C, Wennerberg J, Lydryp ML, et al. The economic burden of human papillomavirus-related precancers and cancers in Sweden. PLoS One. 2017;12:e0179520.

14. Drolet M, Bénard É, Boily MC, Ali H, Baandrup L, Bauer $\mathrm{H}$, et al. Population-level impact and herd effects following human papillomavirus vaccination programmes: a systematic review and meta-analysis. Lancet Infect Dis. 2015;15:565-80.

15. Herweijer E, Leval A, Ploner A, Eloranta S, Simard JF, Dillner $J$, et al. Association of varying number of doses of quadrivalent human papillomavirus vaccine with incidence of condyloma. JAMA. 2014;311:597-603.

16. Herweijer E, Sundström K, Ploner A, Uhnoo I, Sparén $P$, Arnheim-Dahlström L. Quadrivalent HPV vaccine effectiveness against high-grade cervical lesions by age at vaccination: A population-based study. Int J Cancer. 2016;138:2867-74. Erratum in: Int J Cancer. 2017;141:E1-E4.

17. Bogaards JA, Wallinga J, Brakenhoff RH, Meijer CJ, Berkhof J. Direct benefit of vaccinating boys along with girls against oncogenic human papillomavirus: bayesian evidence synthesis. BMJ. 2015;350:h2016.
18. [No Authors]. World Health Organization. IARC Monographs on the Evaluation of Carcinogenic Risks to Humans. Lyon, France: International Agency for Research on Cancer; 2007. International Agency for Research on Cancer. Human papillomaviruses. 2007; p. 90.

19. Gross G, Pfister H. Role of human papillomavirus in penile cancer, penile intraepithelial squamous cell neoplasias and in genital warts. Med Microbiol Immunol. 2004;193:35-44.

20. Bezerra AL, Lopes A, Landman G, Alencar GN, Torloni H, Villa LL. Clinicopathologic features and human papillomavirus dna prevalence of warty and squamous cell carcinoma of the penis. Am J Surg Pathol. 2001;25:673-8.

21. Wiener JS, Effert PJ, Humphrey PA, Yu L, Liu ET, Walther PJ. Prevalence of human papillomavirus types 16 and 18 in squamous-cell carcinoma of the penis: a retrospective analysis of primary and metastatic lesions by differential polymerase chain reaction. Int J Cancer. 1992;50:694-701.

22. Lont AP, Kroon BK, Horenblas S, Gallee MP, Berkhof $J$, Meijer CJ, et al. Presence of high-risk human papillomavirus DNA in penile carcinoma predicts favorable outcome in survival. Int $\mathrm{J}$ Cancer. 2006;119:1078-81.

23. Palefsky JM. Human papillomavirus-related disease in men: not just a women's issue. J Adolesc Health. 2010;46(4 Suppl):S12-9. Erratum in: J Adolesc Health. 2010;46:614.

24. Estudo Epidemiológico sobre a Prevalência Nacional de Infecção pelo HPV (POP-Brasil): Resultados preliminares - Associação Hospitalar Moinhos de Vento - Porto Alegre, 2017120 p. ISBN 978-8598016-00-9

25. [No Authors[. HPV e câncer - Perguntas mais frequentes. INCA. Available at. <http://www2. inca.gov.br/wps/wcm/connect/tiposdecancer/site/ home/colo_utero/hpv-cancer-perguntas-maisfrequentes>

26. Brunini R: Câncer no Brasil: Dados histopatológicos: 1976-80, Ministério da Saúde - Campanha Nacional de Combate ao Câncer, 1982.

Antonio Augusto Ornellas, MD

Departamento de Urologia, Instituto Nacional do Câncer do Brasil (INCA)

Praça da Cruz Vermelha, 23

Rio de Janeiro, RJ, Brasil E-mail: ornellasa@hotmail.com 